\section{JURNAL ABDIMAS

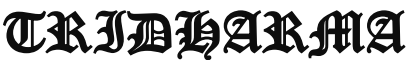

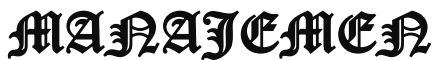

P-ISSN 2615-6849, E-ISSN 2622-3686

Jurnal ABDIMAS Vol. 2, No. 2, April 2021,Hal (68-79)

@ Prodi Manajemen Fakultas Ekonomi Universitas Pamulang

Email: abdimasjurnal.unpam@gmail.com Telp: (021) 741-2566

\title{
SIMPOSIUM TENTANG PENTINGNYA PENDIDIKAN TINGKAT TINGGI UNTUK MENINGKATKAN KAPABILITAS DIRI DALAM \\ DUNIA USAHA PADA SISWA KELAS XII MADRASAH ALIYAH PONDOK PESANTREN AL-MANAR CIBEUTEUNG UDIK, KECAMATAN CISEENG, KABUPATEN BOGOR
}

\author{
Jamaludin*, Masran Mustakim, Nurmin Arianto, Suryadi Marthadinata, \\ Nahoras Bona Simarmata,
}

\begin{abstract}
Dosen Prodi Manajemen Fakultas Ekonomi Universitas Pamulang
Email : dosen01020@unpam.ac.id,dosen01037@unpam.ac.id, dosen01118@unpam.ac.id, dosen01196@unpam.ac.id,
\end{abstract}

\begin{abstract}
ABSTRAK
Pengabdian Kepada Masyarakat (PKM) merupakan salah satu darma dari tri dharma perguruan tinggi, maka dari itu melakukan PKM merupakan suatu keharusan bagi Dosen minimal 1 kali dalam satu semester. Adapun tujuan dari kegiatan Pengabdian Kepada Masyarakat adalah untuk mengetahui cara Meningkatkan keyakinan diri siswa/siswi akan pentingnya pendidikan tingkat tinggi; untuk Memberikan panduan solusi pada siswa/siswi terhadap kendala dalam mewujudkan mengenyam pendidikan tingkat tinggi, dan bagaimana Meningkatkan Kapabilitas Diri Dalam Dunia Usaha.

Supaya PKM ini tepat sasaran, maka perlu diperhatikan metode pelaksanaan PKM. Adapun metode pelaksanaan PKM ini adalah dengan cara: Dalam melaksanakan kegiatan PKM ini digunakan beberapa metode yaitu: 1. Metode Ceramah / Presentasi, Metode ceramah / presentasi dipilih untuk memberikan penjelasan mengenai: a. Memberikan pengetahuan terkait pentingnya pendidikan tinggi; b. Memberikan pengetahuan terkait dengan cara Bagaimana caranya siswa/siswi bisa mewujudkan dirinya agar bisa mengenyam pendidikan di perguruan tinggi; 2 . Metode Tanya Jawab. Metode Tanya jawab sangat penting bagi para peserta. Metode ini memungkinkan para Siswa menggali pengetahuan sebanyak-banyaknya tentang Pentingnya Pendidikan Tinggi 3. Sharing Session. Tentang Pentingnya pendidikan tinggi di Univerisitas. Sharing session ini diberikan kepada para peserta guna mendorong membimbing Siswa Al-Manar

Adapun hasil dari PKM ini nantinya akan dievaluasi berdasarkan taraf penyelesaian materi pelatihan, dan selanjutnya tim kegiatan PKM akan melakukan evaluasi tersebut dengan mengamati dan memeriksa metode pelaksanaan yang sudah dirancang dan yang telah diberikan kepada Siswa Al-Manar.
\end{abstract}

Keywords: Pendidikan tinggi, Kapabilitas Dunia Usaha 


\section{JURNAL ABDIMAS

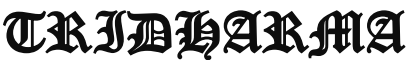

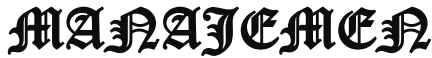

P-ISSN 2615-6849, E-ISSN 2622-3686

Jurnal ABDIMAS Vol. 2, No. 2, April 2021,Hal (68-79)

@ Prodi Manajemen Fakultas Ekonomi Universitas Pamulang

Email: abdimasjurnal.unpam@gmail.com Telp: (021) 741-2566

\begin{abstract}
Community Service (PKM) is one of the principles of the Tri Dharma of Higher Education, therefore doing PKM is a must for Lecturers at least once a semester. The purpose of Community Service activities is to find out how to increase students' self-confidence in the importance of higher education; to provide guidance on solutions to students / students against obstacles in realizing higher education, and how to Improve Personal Capability in the Business World. In order for this PKM to be right on target, it is necessary to pay attention to the method of implementing PKM. The method of implementing this PKM is by: In carrying out this PKM activity several methods are used, namely: 1. Lecture / Presentation Method, The lecture / presentation method is chosen to provide an explanation of: a. Provide knowledge related to the importance of higher education; b. Providing knowledge related to how students can manifest themselves so that they can get education in tertiary institutions; 2. Question and Answer Method. The question and answer method is very important for the participants. This method allows students to gain as much knowledge as possible about the Importance of Higher Education 3. Sharing Session. About the importance of higher education at universities. This sharing session was given to the participants to encourage guiding Al-Manar Students The results of this PKM will later be evaluated based on the level of completion of the training material, and then the PKM activity team will carry out the evaluation by observing and checking the implementation methods that have been designed and that have been given to Al-Manar Students.
\end{abstract}

\title{
Keywords: Higher education, Business World Capability
}

\section{PENDAHULUAN}

Perguruan tinggi merupakan sarana institusi bagi para siswa/siswi yang telah tamat untuk melanjutkan pendidikannya menjadi mahasiswa. Sudah menjadi keniscayaan mahasiswa menjadi tulang punggung negara dalam melanjutkan estafet kepemimpinan di masa-masa mendatang dan mengisi pembangunan di segala bidang kehidupan. Artinya seperti apa nantinya jadinya sebuah Negara dan kehidupan masyarakatnya tidak akan lepas dari kreativitas pemikiran para mahasiswa. Kelompok mahasiswa dalam kehidupan sosial mendapatkan stratifikasi tempat dan peran yang teramat penting sebagai kelompok pemikir elit. Kepada merekalah sebenarnya masa depan suatu bangsa amat ditentukan apakah bergulir menuju kebobrokan ataukah menuju kecerahan. Hal tersebut karena mahasiswa memiliki berbagai fungsi strategis sebagai agent of change, transfer of knowledge, transfer of ideology, indicator of national or political stability, agent of globalization, dan human transformer.

Hal ini menjadi sangat krusial jika dikaitkan dengan pengajaran di lembaga pendidikan tinggi yang tentunya harus mengedepankan output dan outcome yang memiliki kompetensi sesuai dengan bidang ilmunya. Artinya 


\section{JURNAL ABDIMAS

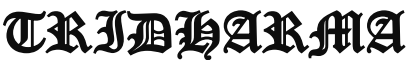

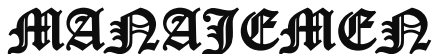

P-ISSN 2615-6849, E-ISSN 2622-3686

Jurnal ABDIMAS Vol. 2, No. 2, April 2021,Hal (68-79)

@Prodi Manajemen Fakultas Ekonomi Universitas Pamulang

Email: abdimasjurnal.unpam@gmail.com Telp: (021) 741-2566 perguruan tinggi tidak hanya menghasilkan produk lulusan yang kompeten, akan tetapi bisa diserap oleh istitusi atau organisasi pengguna lulusan, baik dalam tataran birokrasi pemerintahan, sipil atau militer, perusahaan swasta ataupun negeri, maupun organisasi kemasyarakatan lainnya.

Ditambah lagi dengan faktor globalisasi, membuat situasi menjadi semakin kompetitif dan global, sehingga pendidikan tinggi menjadi sesuatu yang mutlak untuk meningkatkan syarat kompetensi bagi seseorang. Apalagi keberadaan seseorang yang tidak lagi terbatas pada satu negara saja, tetapi melintas ke beberapa negara lain, maka membutuhkan kompetensi yang semakin detail dan kompleks pula.

Dikarenakan gambaran kenyataaan kondisi seperti di atas, perlu kiranya mendapatkan respon dari para siswa/siswi untuk segera meyakinkan dirinya membuat pilihan pada Perguruan Tinggi apapun kendala yang dihadapi. Memang pilihan untuk melanjutkan ke pendidikan tinggi bukanlah satu-satunya jawaban bagi siswa/siswi untuk mengembangkan dirinya dan mencari hidup, ada berbagai pilihan lain misalnya langsung mencari kerja. Namun demikian perlu disadari bahwa ke depannya lulusan perguruan tinggi akan memainkan peranan yang sangat dominan untuk kemajuan kehidupan dalam berbagai bidang sekaligus membangkitkan kekuatan dan potensi diri seseorang.

Kita tahu bahwa semua orang di dunia ini mempunyai kekuatan yang bersumber dari dirinya, namun seringkali masih dalam bentuk potensi.
Banyak ahli Psikologi berpendapat bahwa setiap individu mampu mengembangkan dirinya dan mengubah menjadi lebih baik. Kendati demikian, ternyata banyak juga yang merasa tidak mempunyai kelebihan, tak berguna dan sulit menapak pada kebutuhan puncak menurut Maslow yakni mencapai aktualisasi diri. Oleh karena itu banyak yang terhambat pengembangan dirinya dan membutuhkan tekanan internal dan eksternal tertentu agar berkembang dengan lebih baik. Robbins (dalam Santi, 2005) menyatakan bahwa perubahan seseorang (termasuk pengembangan diri) harus memiliki 3 keyakinan dasar dalam dirinya, yaitu : 1) ia mau berubah, 2) ia harus berubah, dan 3) ia dapat berubah. Berdasarkan pandangan tersebut dapat disimpulkan bahwa pengembangan diri individu memerlukan kesadaran untuk mengenali diri dan motivasi untuk berubah, serta pengetahuan tentang cara-cara pengembangan diri.

Sejak dulu kala banyak orang bijak yang menyarankan untuk mengenali diri. Socrates terkenal dengan katakatanya "cogito orgo sum" kenalilah dirimu, karena dengan cara mengenali diri maka diharapkan dapat menjalani kehidupan secara lebih efektif. Sun Tzu (400 SM) menjelaskan 3 dalil tentang pentingnya mengenal diri, yakni : a) jika kamu mengenal dirimu dan mengenal musuhmu, maka kamu sudah berada di ambang kemenangan, b) jika kamu mengenal dirimu, namun tidak mengenal musuhmu, maka peluang menang adalah sama besar, c) jika kamu tidak mengenal dirimu dan tidak mengenal musuhmu, maka kamu pasti akan kalah dalam setiap pertempuran (Koentjoro, 2005). Dengan melihat latar belakang tersebut maka tema PKM ini 


\section{JURNAL ABDIMAS

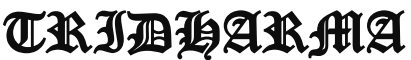

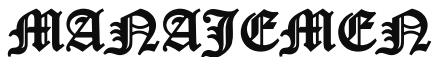

P-ISSN 2615-6849, E-ISSN 2622-3686

Jurnal ABDIMAS Vol. 2, No. 2, April 2021,Hal (68-79)

@Prodi Manajemen Fakultas Ekonomi Universitas Pamulang

Email: abdimasjurnal.unpam@ gmail.com Telp: (021) 741-2566

\begin{abstract}
adalah "Simposium Tentang Pentingnya Pendidikan Tingkat Tinggi Untuk Meningkatkan Kapabilitas Diri Dalam Dunia Usaha Di Kecamatan Ciseeng Kabupaten Bogor"
\end{abstract}

\section{RUMUSAN MASALAH}

Rumusan masalah yang akan di pecahkan melalui program ini pada dasarnya tidak lepas dari ruang lingkup masalah diatas, adapun perumusan masalah dalam kegiatan ini adalah:

1. Bagaimana caranya siswa/siswi meyakinkan dirinya akan pentingnya pendidikan tingkat tinggi?

2. Bagaimana caranya siswa/siswi bisa mewujudkan dirinya agar bisa mengenyam pendidikan di perguruan tinggi?

3. Bagaimana meningkatkan kapabilitas Diri dalam dunia usaha?

\section{TUJUAN PELAKSANAAN}

Berdasarkan pada permasalahan yang ada, maka kegiatan Pengabdian Kepada Masyarakat ini bertujuan unuk: 1. Untuk mengetahui cara Meningkatkan keyakinan diri siswa/siswi akan pentingnya pendidikan tingkat tinggi.

2. Untuk Memberikan panduan solusi pada siswa/siswi terhadap kendala dalam mewujudkan mengenyam pendidikan tingkat tinggi.

3. Untuk mengetahui cara meningkatkan kapabilitas Diri dalam dunia usaha

\section{MANFAAT MASYARAKAT}

Adapun manfaat yang dapat diambil dari kegiatan Pengabdian masyarakat ini adalah sebagai berikut:

1. Bagi Siswa/Siswi; diharapkan siswa/siswi mampu memahami dan memaknai arti penting dari pentingnya pendidikan tingkat tinggi melalui konsep keyakinan diri yang mantap dan visioner.

2. Bagi sekolah; dapat mewujudkan siswa/siswinya agar bisa melanjutkan sekolah ke jenjang perguruan tinggi, menjadi sarjana yang kompetitif, sehingga nantinya kelak bisa mengharumkan nama sekolah jika sudah sukses di masyarakat.

3. Bagi para Dosen; dapat berbagi ilmu pengetahuan dan pengalaman secara langsung dengan siswa/siswi khsusnya tentang arti penting dari hakikat melanjutkan pendidikan di perguruan tinggi dan implikasinya nanti setelah terjun dalam dunia bisnis.

\section{TINJAUAN PUSTAKA}

1. Pengertian Pendidikan Tinggi

Menurut UU No. 12 Tahun 2012 tentang Pendidikan Tinggi pada pasal 1 ayat (1) bawha "Pendidikan Tinggi adalah jenjang pendidikan setelah pendidikan menengah yang mencakup program diploma, program sarjana, program magister, program doktor, dan program profesi, serta program spesialis, yang diselenggarakan oleh perguruan tinggi berdasarkan kebudayaan bangsa Indonesia."

Pendidikan Tinggi adalah jenjang pendidikan setelah pendidikan menengah yang mencakup program diploma, program sarjana, program magister, 


\section{JURNAL ABDIMAS

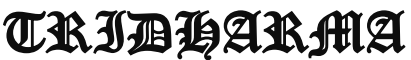

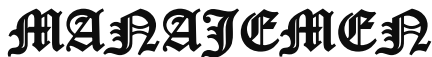

P-ISSN 2615-6849, E-ISSN 2622-3686

Jurnal ABDIMAS Vol. 2, No. 2, April 2021,Hal (68-79)

@Prodi Manajemen Fakultas Ekonomi Universitas Pamulang

Email: abdimasjurnal.unpam@ gmail.com Telp: (021) 741-2566 program doktor, dan program profesi, serta program spesialis, yang diselenggarakan oleh perguruan tinggi berdasarkan kebudayaan bangsa Indonesia.

Perguruan tinggi adalah tahap akhir opsional pada pendidikan formal. Biasanya disampaikan dalam

bentuk universitas, akademi, colleg es, seminari, sekolah musik, dan institut teknologi. Peserta didik perguruan tinggi disebut mahasiswa, sedangkan tenaga pendidiknya disebut dosen. Berdasarkan kepemilikannya, perguruan tinggi dibagi menjadi dua, yaitu: perguruan tinggi negeri dan perguruan tinggi swasta (Wikipedia.com).

Pendidikan Tinggi merupakan jenjang pendidikan setelah pendidikan menengah (SMK/SMA/MA). Program yang ada dalam pendidikan tinggi ini tidak hanya sarjana (S-1) melainkan diploma, pendidikan profesi, magister (S-2), bahkan doktor (S-3). Sedangkan satuan pendidikan yang menyelenggarakan pendidikan tinggi ini dikenal dengan nama Perguruan Tinggi (PT), baik itu Perguruan Tinggi Negeri (PTN) maupun Perguruan Tinggi Swasta (PTS). Perguruan Tinggi ini terdiri dari beberapa bentuk, yaitu: universitas, institut, sekolah tinggi, politeknik, akademi, dan akademi komunitas (Wahyono, 2015).

\section{Fungsi dan Tujuan Pendidkan Tinggi \\ Fungsi Pendidikan Tinggi}

Pendidikan Tinggi memiliki beberapa fungsi, sebagaimana disebutkan dalam UU No. 12 Tahun 2012 Pasal 4 bahwa pendidikan tinggi memiliki 3 (tiga) fungsi sebagai berikut:

1. Mengembangkan kemampuan dan membentuk watak serta peradaban bangsa yang bermartabat dalam rangka mencerdaskan kehidupan bangsa.

2. Mengembangkan Sivitas Akademika yang inovatif, responsif, kreatif, terampil, berdaya saing, dan kooperatif melalui pelaksanaan Tridharma, dan

3. Mengembangkan Ilmu Pengetahuan dan Teknologi dengan memperhatikan dan menerapkan nilai Humaniora.

\section{Tujuan Pendidikan Tinggi}

Selain memiliki fungsi, pendidikan tinggi juga memiliki beberapa tujuan. Seperti halnya pengertian dan fungsi pendidikan tinggi, tujuan pendidikan tinggi juga tertuang dalam UU No. 12 Tahun 2012 tentang Pendidikan Tinggi yaitu pada pasal 5. Dalam UU No. 12 Tahun 2012 pasal 5 tersebut disebutkan 4 (empat) tujuan pendidikan tinggi, yaitu sebagai berikut:

1. Berkembangnya potensi Mahasiswa agar menjadi manusia yang beriman dan bertakwa kepada Tuhan Yang Maha Esa dan berakhlak mulia, sehat, berilmu, cakap, kreatif, mandiri, terampil, kompeten, dan berbudaya untuk kepentingan bangsa.

2. Dihasilkannya lulusan yang menguasai cabang Ilmu Pengetahuan dan/atau Teknologi untuk memenuhi kepentingan nasional dan peningkatan daya saing bangsa. 


\section{JURNAL ABDIMAS

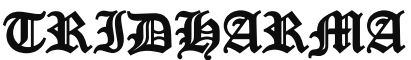

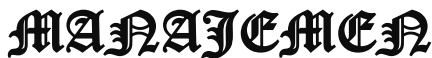

P-ISSN 2615-6849, E-ISSN 2622-3686

Jurnal ABDIMAS Vol. 2, No. 2, April 2021,Hal (68-79)

@Prodi Manajemen Fakultas Ekonomi Universitas Pamulang

Email: abdimasjurnal.unpam@gmail.com Telp: (021) 741-2566
3. Dihasilkannya Ilmu Pengetahuan dan Teknologi melalui Penelitian yang memperhatikan dan menerapkan nilai Humaniora agar bermanfaat bagi kemajuan bangsa, serta kemajuan peradaban dan kesejahteraan umat manusia.

4. Terwujudnya Pengabdian kepada Masyarakat berbasis penalaran dan karya Penelitian yang bermanfaat dalam memajukan kesejahteraan umum dan mencerdaskan kehidupan bangsa.

Asas Pendidikan Tinggi

- Kebenaran ilmiah;

- Penalaran;

- Kejujuran;

- Keadilan;

- Manfaat;

- Kebajikan;

- Tanggung jawab;

- Kebhinnekaan; dan

- Keterjangkauan.

B. Membangkitkan semangat berwirausaha

Sebagai seorang pengusaha atau calon pengusaha, tentunya spirit dalam menjalankan usaha tidak boleh luntur atau patah semangat. Motivasi usaha merupakan suatu hal penting yang harus ada dalam diri setiap entrepreneur muda atau yang sudah berpengalaman.

Tanpa adanya sebuah motivasi, bisa dipastikan segala sesuatunya termasuk impian yang selama ini diidam-idamkan akan terasa sangat sulit untuk dicapai dan diperluas kesuksesannya.

Sebenarnya salah satu kunci untuk mendapat kesuksesan adalah dengan pantang menyerah serta tidak patah semangat dalam segala kondisi apapun. Maka dari itu, untuk membantu kesuksesan seluruh calon pengusaha serta pengusaha yang telah berkecimpung dalam dunia bisnis

\section{METODE PELAKSANAAN}

Dalam melaksanakan kegiatan PKM ini digunakan beberapa metode yaitu:

1. Metode Ceramah/Presentasi, Metode ceramah/ presentasi dipilih untuk memberikan penjelasan mengenai:

a. Memberikan pengetahuan terkait dengan pentingnya pendidikan tinggi

b. Memberikan pengetahuan terkait dengan pendidikan tinggi dalam memberikan minat berwirausaha.

c. Memberikan pengetahuan terkait dengan cara menumbuhkan dan membangkitkan semangat berwirausaha

2. Metode Tanya Jawab

Metode Tanya jawab sangat penting bagi para peserta. Metode ini memungkinkan perseta PKM mendapatkan pemahaman tentang pentingya pendidikan tinggi

3. Sharing Session. Tentang Pentingnya pendidikan tinggi dan minat berwirausaha.

\section{PEMBAHASAN}

1. Sejarah singkat Pondok Pesantren Al-Manar

Pondok Pesantren Almanar berlokasi di desa cibeuteng udik kec. Ciseeng, kab. Bogor, provinsi jawa barat. didirikan oleh Drs.H.Marwan Saridjo 1999 di atas lahan seluas 2,5 Ha. pada tanggal 26 oktober $1999 \mathrm{M}$ bertepatan dengan 16 Rajab 1420 hijriah, diresmikan oleh menteri 


\section{JURNAL ABDIMAS

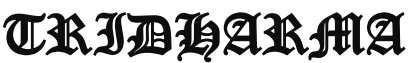

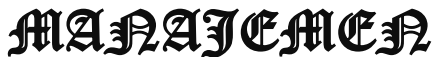

P-ISSN 2615-6849, E-ISSN 2622-3686

Jurnal ABDIMAS Vol. 2, No. 2, April 2021,Hal (68-79)

@Prodi Manajemen Fakultas Ekonomi Universitas Pamulang

Email: abdimasjurnal.unpam@gmail.com Telp: (021) 741-2566 agama Prof. A. Malik Fajar. Pada tahun 1999 mulai membuka satuan pendidikan sebagai berikut:

1. Madrasah Tsanawiyah( MTs )

2. Madrasah Aliyah (MA)

3. Madrasah Diniyah

Setelah setahun berjalan dibuka lagi satuan pendidikan yang lain, yaitu - sekolah menengah kejuruan ( SMK ); - sekolah taman kanak kanak islam ( TKI); - madrasah ibtidaiyah (MI) sampai sekarang (2020), jumlah satuan pendidikan di bawah naungan yayasan Ngali Aksara Almanar( pondok pesantren) sebanyak 6 satuan pendidikan.

Sejak berdirinya sampai sekarang (2020), satuan pendidikan pesantren almanar, proses belajar mengajar alhamdullilah berjalan dengan lancar dan baik berkat dukungan tenaga pengajar yang profesional dan berpendidikan strata dua.

Latar belakang pendirian:

1. Bahwa didesa Cibeuteung Udik dan sekitarnya, belum ada satuan pendidikan setingkat SMP/ MTs, SMA/ MA

2. Dalam rangka membantu pemerintah untuk menuntaskan wajib belajar 9 tahun

3. Atas kerja sama DPP GUPPI dengan yayasan Ngali Aksara Almanar

2. Bagaimana caranya siswa/siswi meyakinkan dirinya akan pentingnya pendidikan tingkat tinggi?

Kegiatan pendidikan adalah aspek penting dan sangat vital dalam kehidupan umat manusia baik secara individu maupun kolektif. Saking pentingnya pendidikan itu, membuat berbagai negara di dunia yang paling makmur dan maju sekalipun mengeluarkan berbagai usaha untuk memajukan sekolah dan pendidikannya dalam berbagai cara.

Berdasarkan Undang-Undang Nomor 20 Tahun 2003 pasal 3, tujuan umum pendidikan nasional adalah untuk berkembangnya potensi peserta didik agar menjadi manusia yang beriman dan bertakwa kepada Tuhan Yang Maha Esa, berakhlak mulia, sehat, berilmu, cakap, kreatif, mandiri dan menjadi warga negara yang demokratis serta bertanggungjawab.

Pendidikan adalah kunci dari pembelajaran dalam diri seseorang sebagai bekal dalam menjalani kehidupan sekarang dan yang akan datang. Pendidikan mengajarkan manusia untuk berfikir, memahami, berinovasi serta mempraktekkan apa yang telah didapat dalam proses pendidikan tersebut. Tanpa adanya pendidikan tentu seseorang tersebut menjadi terbelakang, tidak berilmu, tidak mempunyai keterampilan dan minim wawasan pengetahuan. Hal tersebut pada akhirnya berdapampak kepada sumber daya manusia yang terbatas, tanpa kualitas dan sudah pasti tidak memiliki daya saing.

Semua orang tahu bahwa abad 21 merupakan suatu masa yang diwarnai oleh munculnya era teknologi informasi dan komunikasi. Fenomena ini merupakan era baru peradaban manusia dimana terjadi perubahan yang sangat cepat dalam berbagai bidang kehidupan. Teknologi dan ilmu pengetahuan berkembang sangat pesat dengan didukung oleh proses transformasi 


\section{JURNAL ABDIMAS

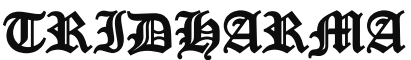

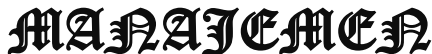

P-ISSN 2615-6849, E-ISSN 2622-3686

Jurnal ABDIMAS Vol. 2, No. 2, April 2021,Hal (68-79)

@Prodi Manajemen Fakultas Ekonomi Universitas Pamulang

Email: abdimasjurnal.unpam@gmail.com Telp: (021) 741-2566 informasi sedemikian rupa sehingga mengakibatkan perubahan pola hidup manusia. Era informasi merupakan gelombang ketiga dari peradaban dunia. Dimana era sebelumnya adalah era pertanian dan era industri.

Jika kita amati dengan teliti ada perbedaan yang menyolok diantara ketiga era tersebut, pada era pertanian yang menonjol agar tetap survive adalah otot, karena pada saat itu produktivitas ditentukan oleh otot. Dalam era industri faktor yang menonjol adalah mesin, pekerjaan "otot" mulai digantikan dengan pekerjaan mesin, karena terbukti lebih efektif dan efisien. Sedangkan dalam era informasi, faktor yang menonjol adalah pikiran dan pengetahuan individu dan organisasi (Baskoro, 2009).

Perubahan "dunia" telah memberikan dampak baik positif maupun negatif pada suatu bangsa yang telah "kabur" batas kewilayahannya. Abad ke-21 diprediksi merupakan era ekonomi pengetahuan, diduga akan terjadi perubahan secara cepat, terusmenerus, dan penuh ketidakpastian yang menuntut SDM berkemampuan tinggi (intelektual dan keterampilan) sebagai modal dalam berbisnis. Perekonomian baru di abad ke-21, akan banyak ditandai oleh globalisasi, pembiasaan masyarakat, perdagangan produk, efisiensi biaya, efisiensi staf, servis pelanggan, kompleksitas proses bisnis, swalayan, dan perdagangan secara elektronik (e-commerce).

Kemampuan SDM yang mumpuni dan unggul tersebut salah satunya akan dilahirkan dari banyaknya lulusanlulusan dari dunia pendidikan yang bermutu dan berkelanjutan.

\section{Bagaimana caranya siswa/siswi bisa mewujudkan dirinya berwirausaha saat mengenyam pendidikan di perguruan tinggi?}

Agar mampu menghasilkan para wirausaha muda, perguruan tinggi terlebih dahulu harus mampu merubah eksistensi lembaganya menjadi sebuah entrepreneurial university (EU). Menurut Gupta (2008) secara kongkrit EU memiliki makna,

1. pertama perguruan tinggi dapat menjadi lembaga kewirausahaan sebagai suatu organisasi dengan memanfaatkan secara optimum dan efisien sumber daya (khususnya SDM) yang dimiliki.

Makna pertama dapat diimplementasikan secara nyata dalam bentuk pemanfaatan peluang dengan memproduksi barang dan jasa dengan menggunakan secara optimal dan efisien semua sumber daya, seperti uang, bahan baku, teknologi, mesin, keterampilan, dan tenaga kerja agar menghasilkan produk yang berdaya saing dan menguntungkan.

2. Kedua, para mahasiswa, staf pengajar dan fakultas terintegrasi dengan lembaga bisnis, industri, dan komunitas (stakeholders) melalui inovasi dan pengenalan ilmu pengetahuan dan kerjasama dengan industri.

Makna kedua dapat diimplementasikan secara nyata dalam bentuk komitmen seluruh anggota perguruan tinggi, seperti mahasiswa, staf dosen, karyawan, manajemen, bahkan pihak yayasan terhadap semangat, dorongan, dukungan dalam mewujudkan perguruan tinggi sebagai pusat kewirausahaan. 


\section{JURNAL ABDIMAS

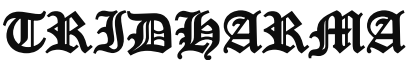

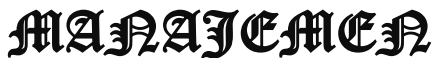

P-ISSN 2615-6849, E-ISSN 2622-3686

Jurnal ABDIMAS Vol. 2, No. 2, April 2021,Hal (68-79)

@Prodi Manajemen Fakultas Ekonomi Universitas Pamulang

Email: abdimasjurnal.unpam@gmail.com Telp: (021) 741-2566
Lebih lanjut komitmen tersebut harus diwujudkan dalam tindakan nyata dalam bentuk menciptakan hubungan timbal balik antara perguruan tinggi dengan berbagai stakeholders yang ada di lingkungan perguruan tinggi, seperti organisasi bisnis, industri, pemerintah, dan komunitas masyarakat termasuk alumni. Hubungan timbal balik yang baik antara perguruan tinggi sebagai pusat kewirausahaan dengan berbagai stakeholders dapat memberikan keuntungan bagi kedua belah pihak.

Perguruan tinggi membutuhkan berbagai informasi dan dukungan kerjasama dari organisasi bisnis, industri, komunitas masyarakat, alumni dan pemerintah agar mampu menghasilkan lulusan yang mampu menciptakan lapangan kerja. Sebaliknya perguruan tinggi dapat memberikan transfer ilmu pengetahuan maupun produk teknologi hasil riset yang dapat dimanfaatkan untuk pengembangan sesuai kebutuhan lembaga yang bersangkutan.

\section{Bagaimana meningkatkan kapabilitas Diri dalam dunia usaha.}

Menurut Priharto (2020) bahwa kiatkita penting agar motivasi dalam usaha tidak pernah padam, anatara lain:

\section{Mempunyai Goals Atau Tujuan} yang Nyata. Tentunya sebagai seorang entrepreneur pasti ada tujuan atau goals yang dicapai. Entah itu saat baru pertama kali mencoba atau saat yang sudah berjalan. Sebagian goals tersebut pastinya ada yang secara spesifik maupun yang hanya sebagai pelengkap.
2. Selalu Mematok Kesuksesan Seorang Pengusaha Sebagai Sebuah Contoh Hidup. Tidak bisa dipungkiri memang, kebanyakan seorang pengusaha yang terkenal pasti mempunyai kisah-kisah menariknya sendiri. Hal itulah yang menjadi tujuan serta hal menarik bagi setiap calon pengusaha atau entrepreneur muda yang ingin sukses kedepannya. Dengan melihat kisah sukses seorang pengusaha maka dari dalam diri terbentuk motivasi yang otomatis juga akan tumbuh semangat untuk menjadi lebih baik kedepan nya.

\section{Ikut Ke Dalam Komunitas} Pengusaha. Sebagai seorang entrepreneur, bergabung kedalam sebuah komunitas merupakan hal wajib yang harus diikuti. Karena seorang pengusaha pasti membutuhkan teman atau kelompok dalam mengembangkan usahanya.

4. Hal-hal Sehat Wajib Dijalankan.

Sebagai seorang entrepreneur, dalam mengejar sebuah jalan kesuksesan pasti akan mendapat berbagai rintangan dan juga halangan di depannya. Tentu saja hal tersebut akan memberikan berbagai dampak, mulai dari stress, kesehatan menurun, dan hal terparahnya adalah sebuah rasa depresi.

5. Membuat Jadwal Rutin Setiap Pagi. Untuk meningkatkan produktivitas serta menjaga agar tetap produktif setiap hari, maka menjadwalkan agenda setiap pagi adalah hal yang wajib dilakukan oleh setiap entrepreneur muda. Salah satu motivasi usaha yang satu ini tentu akan membuat hari-hari 


\section{JURNAL ABDIMAS

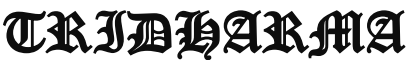

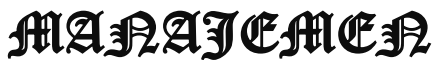

P-ISSN 2615-6849, E-ISSN 2622-3686

Jurnal ABDIMAS Vol. 2, No. 2, April 2021,Hal (68-79)

@Prodi Manajemen Fakultas Ekonomi Universitas Pamulang

Email: abdimasjurnal.unpam@ gmail.com Telp: (021) 741-2566 menjadi lebih produktif dan lebih siap menghadapi kegiatan atau aktivitas yang akan mencapai tujuan Anda.

6. Selalu Memasang 'Alarm' Pribadi. Walaupun telah membuat daftardaftar atau list agenda yang harus dilakukan setiap harinya, belum tentu hal tersebut dapat berjalan sesuai rencana. Karena sebuah motivasi usaha akan hadir jika sang entrepreneur nya selalu fokus.

\section{Melakukan Hal-hal Inspiratif Bagi}

Diri. Dalam membangun dunia usaha yang kuat dan sukses salah satu motivasi usaha yang dapat dilakukan adalah dengan melakukan kegiatan yang bersifat inspirasional. Bisa dengan mendengarkan podcast, bisa dengan melihat film film yang berkisah tentang sebuah kesuksesan. Atau dengan melihat film-film dokumenter yang mengarah pada hal membangun sebuah semangat.

8. Istirahat Cukup. Walaupun terdengar sepele, nyatanya istirahat menjadi salah satu agenda atau kegiatan yang wajib dilakukan. Karena dengan istirahat cukup maka tubuh akan bisa fokus dalam menjalani hari-hari esok, sehingga tidak ada salahnya untuk selalu memiliki waktu istirahat yang cukup.

9. Memberi Apresiasi Terhadap Diri Sendiri. Salah satu kiat motivasi usaha yang utama adalah dengan memberikan apresiasi kepada diri sendiri. Dengan begitu akan ada semangat dan rasa menggebu dalam meraih sebuah target tertentu. Disamping itu, dengan memberi apresiasi kepada diri sendiri adalah sebagai bentuk dalam menghargai jerih payah diri.

10. Selalu Menjaga Detil Keuangan. Yang terpenting dalam membangun dunia usaha adalah dengan selalu membuat list atau melihat bagaimana sistem keuangan berjalan. Baik pengeluaran maupun pemasukan semuanya harus dicek secara detail dan lengkap, jangan sampai ada yang terlewat. Karena dengan mengetahui jumlah uang serta jumlah uang yang masuk, maka suatu usaha akan dapat dilihat sampai dimana akan bertahan dalam jangka waktu yang panjang.

\section{KESIMPULAN DAN SARAN \\ Kesimpulan}

Dari uraian di atas dapat disimpulkan bahwa penyelenggaraan pendidikan kewirausahaan di perguruan tinggi harus dilakukan dengan sungguhsungguh. Banyak hal yang harus diperhatikan dalam penyelenggaraan pendidikan kewirausahaan yang efektif.

Diantaranya terdapat tiga poin penting yang harus diperhatikan. Pertama, membangun komitmen bagi seluruh anggota sivitas akademika memposisikan perguruan tinggi sebagai entrepreneurial university. Hal ini menjadi prasyarat bila ingin penyelenggaraan pendidikan kewirausahaan berhasil dan mampu mencetak wirausahawan yang berasal dari kampus. Kedua, agar pendidikan kewirausahaan dapat diselenggarakan secara efektif harus dipenuhi beberapa aspek penting diantaranya adalah rancangan kurikulum kewirausahaan yang jelas, terarah, dan terintegrasi dengan berbagai kegiatan pendukung. Hal ini sangat dibutuhkan dalam 


\section{JURNAL ABDIMAS

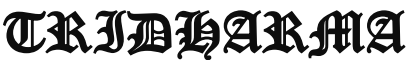

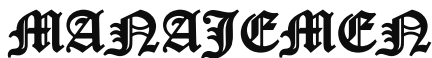

P-ISSN 2615-6849, E-ISSN 2622-3686

Jurnal ABDIMAS Vol. 2, No. 2, April 2021,Hal (68-79)

@Prodi Manajemen Fakultas Ekonomi Universitas Pamulang

Email: abdimasjurnal.unpam@gmail.com Telp: (021) 741-2566 merancang proses pembelajaran yang bertahap dan berkelanjutan. Kurikulum yang sudah dirancang dengan baik tentu tidak bermanfaat banyak bila tidak didukung oleh metode pembelajaran yang tepat. Oleh karena itu penggunaan metode pembelajaran yang berpusat pada mahasiswa (student-centred learning) sangat dianjurkan. Kemudian pemilihan tenaga pengajar/dosen yang memiliki komitmen dan kompetensi di bidang kewirausahaan menjadi mutlak. Dalam hal ini dapat dilakukan dengan mengkombinasikan antara dosen internal dengan tenaga pengajar dari eksternal (pengusaha dan praktisi profesional). Selanjutnya penciptaan atmosfer kewirausahaan atau suasana kewirausahaan juga penting untuk mendukung penyelenggaraan pendidikan kewirausahaan di perguruan tinggi. Bila suasana kewirausahaan di dalam kampus sangat mendukung diharapkan pencapaian tujuan pendidikan kewirausahaan akan lebih mudah diwujudkan. Ketiga, keberhasilan dalam penyelenggaraan pendidikan kewirausahaan di perguruan tinggi sangat ditentukan oleh kemampuan dalam merancang proses pembelajaran. Oleh karena pendidikan kewirausahaan tidak bisa hanya dilakukan dalam jangka pendek, maka perlu merancang proses pembelajaran kewirausahaan yang bertahap dan berkelanjutan.

\section{Saran}

Berdasarkan hasil pembahasan diatas, maka tim PKM menyarankan sebagai berikut:

1. Ibu PKK lebih selektif dalam memilih/membeli kebutuhan (primer, sekunder, dan tersier)

2. Ibu PKK Kelurahan Pondok Benda Lebih bijak dalam menentukan bank yang akan digunakan berdasarkan kebutuhan di masa mendatang.

3. Ibu PKK dapat terus meningkatkan pengetahuan keuangan agar dapat memanfaatkan tabungan yang dimilki di masa mendatang.

\section{DAFTAR PUSTAKA}

Wahyono, Budi. 2015. Pendidikan Ekonomi "Pengertian, Fungsi Dan Tujuan Pendidikan Tinggi'.http://www.pendidikane konomi.com/2015/03/pengertian -fungsi-dan-tujuanpendidikan.html. (Diakses Hari Jumat, 13 November 2020).

Baskoro, A.P. 2009. Mempersiapkan Generasi di Abad 21. (online), (http://baskoro.blogspot.com/ 2009/06/mempersiapkangenerasi-diabad-21- html/,

Gupta, Asha. 2008, "Entrepreneurial University : India's Response", Research \& Occasional Paper Series, CSHE.2.08, University of California, Berkeley, http://cshe.berkeley.edu/publi cations/docs/RO

PS.Gupta.3.5.08.pdf diakses pada 19/01/2013.

Koentjoro. 2005. Meningkatkan Motivasi dan Pemahaman Diri. Makalah Pelatihan. Forest.

Undang-Undang Nomor 12 Tahun 2012 tentang Pendidikan Tinggi.

Pasaribu, V. L. D., Agrasadya, A., Shabrina, N., \& Krisnaldy, K. (2020). Menjadi Enterpreneur Muda 


\section{JURNAL ABDIMAS

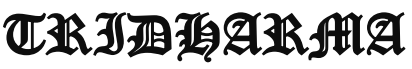

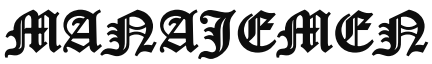

P-ISSN 2615-6849, E-ISSN 2622-3686

Jurnal ABDIMAS Vol. 2, No. 2, April 2021,Hal (68-79)

@Prodi Manajemen Fakultas Ekonomi Universitas Pamulang

Email: abdimasjurnal.unpam@gmail.com Telp: (021) 741-2566
Yang Memiliki Jiwa Leadership Untuk Menghadapi Masa Depan. Abdi Laksana: Jurnal Pengabdian Masyarakat, 1(1).

Pasaribu, V. L. D., Susanti, F., \& Hartuti, E. T. K. (2019). Memotivasi Siswa dan Siswi SMK Letris Indonesia di Dalam Menentukan Pilihan Untuk Melanjutkan Pendidikan Atau Bekerja Setelah Lulus Sekolah. Jurnal Pengabdian Dharma Laksana, 1(2), 161-172.

Priadi, A., Pasaribu, V. L. D., Virby, S., Sairin, S., \& Wardani, W. G. (2020). Penguatan Ekonomi Kreatif Berbasis Sumber Daya Desa Dikelurahan Rempoa. Abdi Laksana: Jurnal Pengabdian Kepada Masyarakat, 1(3), 356-358.

Priharto, Sugi. 2020. Accurate "10 Cara Membangkitkan Usaha Dalam Motivasi Anda".https://accurate.id/bisnisukm/cara-membangkitkanmotivasi-usaha/. (Diakses Hari Jumat, 13 November 2020).

https://id.wikipedia.org/wiki/Perguruan _tinggi

\section{DOKUMENTASI KEGIATAN}

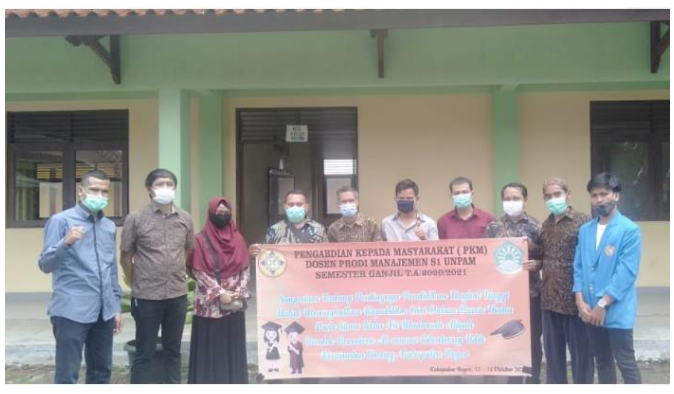

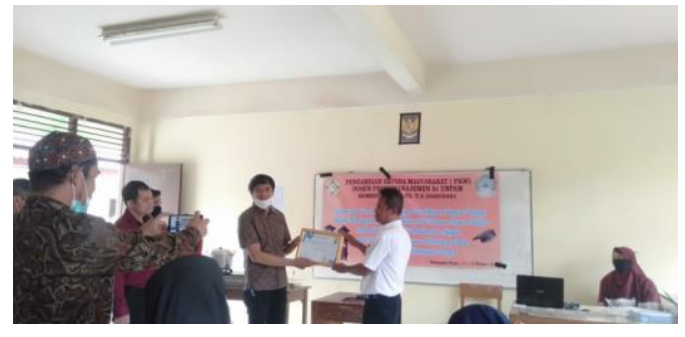
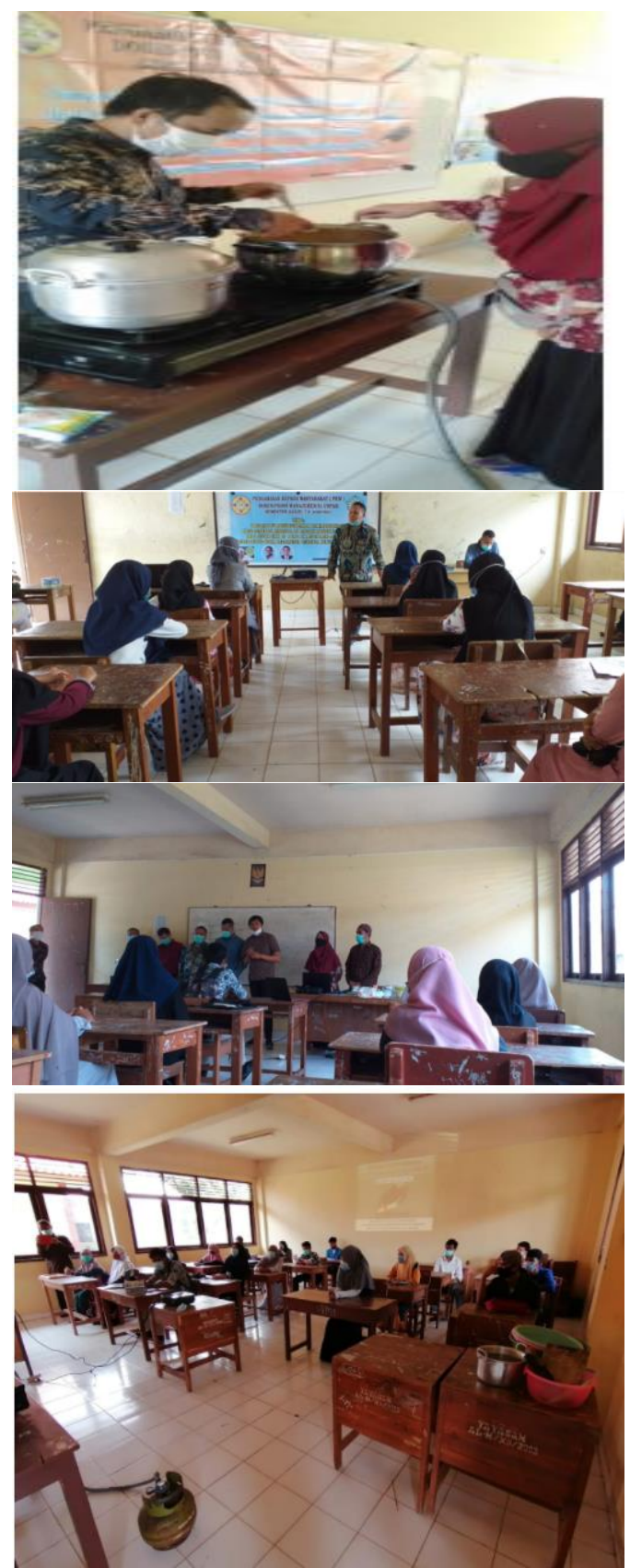